\title{
Analisis Kesulitan Guru Matematika SMP dalam Menyusun Rencana Pelaksanaan Pembelajaran (RPP) Berdasarkan Kurikulum 2013
}

\author{
Rezkiatu Novia Alhikmah ${ }^{1}$, Yenita Roza ${ }^{2}$, Maimunah $^{3}$ \\ 1,2,3 Prodi Pendidikan Matematika Universitas Riau, \\ Kampus Bina Widya KM 12,5, Simpang Baru, Kecamatan Tampan, Pekanbaru Kode Pos 28293, Indonesia \\ Rezkiatu.novia7956@grad.unri.ac.id
}

\begin{abstract}
This research is based on a teacher's lack of knowledge in composing an RPP, so many teachers have difficulty formulating the RPP component. This research aims to analyze the difficulties of the junior high school teacher in drafting an RPP. This research is qualitative's descriptive and the subject consists of 5 math teachers from the 5 secondary schools in the Kuala Kampar district. Collection techniques through documentation and interview. There are two types of data in this research, namely primary and secondary data. There are some difficulties teachers, among others: Teachers have not to adjusted KKO to IPK; Teachers still lack a teacher's grasp of the purpose of learning that notices the requirements of the ABCD; Teachers confused and in determining the fact and concepts so that there are still teachers to combine the two. Based on analysis it could be concluded that teachers had scant training about RPP which resulted in teachers being confused. The solutions which are expected that school provides teachers with training about the RPP; Teachers should search literature about RPP so that teachers get more knowledge; Reactivate the role of MGMP in their district so that fellow teachers can exchange information with each other.
\end{abstract}

Keywords: 2013 Curriculum, difficulties teachers, RPP

\begin{abstract}
Abstrak
Penelitian dilatar belakangi oleh kurangnya pengetahuan guru dalam menyusun RPP, sehingga banyak guru yang mengalami kesulitan dalam menyusun komponen RPP. Tujuan penelitian untuk menganalisis kesulitan guru SMP dalam menyusun RPP. Penelitian ini adalah penelitian deskriptif kualitatif dan subjek penelitian terdiri dari 5 orang guru matematika yang berasal dari 5 sekolah menengah pertama di Kecamatan Kuala Kampar, Kabupaten Pelalawan. Teknik pengumpulan data didapat melalui dokumentasi dan wawancara. Terdapat dua jenis data dalam penelitian, yaitu data primer dan data sekunder. Kesulitan yang dialami guru yaitu: Guru belum bisa menyesuaikan KKO dalam membuat IPK; Kurangnya pemahaman guru tentang tujuan pembelajaran yang memperhatikan syarat ABCD; Guru bingung menentukan fakta dan konsep sehingga masih ada yang menggabungkan keduanya. Berdasarkan hasil analisis dapat disimpulkan bahwa guru minim dalam mendapatkan pelatihan dan seminar tentang penyusunan RPP yang berakibat guru bingung dalam menyusun RPP. Solusi yang diberikan yaitu diharapkan sekolah hendaknya memberikan fasilitas kepada guru untuk mengikuti pelatihan atau webinar tentang penyusunan RPP, guru lebih banyak mencari dan membaca berbagai literatur tentang RPP sehingga mendapatkan pengetahuan yang lebih, serta mengaktifkan kembali peran MGMP di kecamatan nya agar sesama guru dapat saling bertukar informasi.
\end{abstract}

Kata kunci: Kurikulum 2013, Kesulitan Guru, RPP

Copyright (c) 2021 Rezkiatu Novia Alhikmah, Yenita Roza, Maimunah $\triangle$ Corresponding author: Rezkiatu Novia Alhikmah

Email Address: rezkiatu.novia7956@grad.unri.ac.id (Kampus Bina Widya KM 12,5, Simpang Baru, Pekanbaru) Received 28 Desember 2020, Accepted 03 Maret 2021, Published 22 Maret 2021

\section{PENDAHULUAN}

Kurikulum merupakan pedoman penyelenggaraan kegiatan pembelajaran yang menggunakan seperangkat rencana tentang tujuan, isi dan bahan pelajaran sebagai jembatan untuk mencapai tujuan pada tiap satuan pendidikan yang dijabarkan kedalam mata pelajaran sekolah. Menurut (Retnawati, 
2016) tujuan dari kurikulum adalah untuk meningkatkan kualitas dan daya saing bangsa bersamaan dengan berkembangnya ilmu pengetahuan dan teknologi. Selain itu, (Sariono, 2014) menjelaskan bahwa fungsi kurikulum bagi guru adalah sebagai panduan dalam pelaksanaan pembelajaran. Proses pelaksanaan pembelajaran tidak akan berjalan baik apabila tidak mengikuti panduan dari kurikulum, dikarenakan pembelajaran merupakan proses yang bertujuan, sehingga untuk mencapai tujuan, guru dan siswa harus melakukan segala sesuatu dengan terarah. Selanjutnya, (Ratumanan \& Tetelepta, 2019) menyatakan bahwa terdapat dua sisi dalam memandang kurikulum, yang pertama memandang kurikulum sebagai dokumen, yaitu tentang hasil yang didapat dalam pembelajaran, mempelajari materi serta mengukur dan menilai tingkat pencapaian kompetensi. Kedua, memandang kurikulum sebagai bentuk implementasi, yaitu berhubungan dengan rencana pembelajaran dan rencana penilaian. Berdasarkan kedua pendapat tersebut, maka dapat disimpulkan bahwa kurikulum merupakan petunjuk yang dipandang sebagai dokumen dan juga sebagai bentuk impelentasi dalam pelaksanaan pembelajaran yang didalam pelaksanaan tersebut membutuhkan rancangan sebagai jalan untuk mencapai suatu tujuan disetiap satu pendidikan.

Menurut (Winaya et al., 2015) menyatakan bahwa dibutuhkan persiapan yang berbeda dengan pergantian antara kurikulum lama menjadi kurikulum baru. Persiapan ini terdiri dari semua kategori, seperti persiapan guru dalam mengembangkan gagasan dan rancangan pembelajaran yang akan diberikan kepada siswa sehingga siswa mampu dalam mempelajari dan memahami pembelajaran. Oleh karena itu, seorang guru terlebih dahulu harus menyesuaikan kurikulum yang berlaku dalam merancang pembelajaran. Proses pembuatan perangkat pembelajaran didalam pelaksanaan kurikulum 2013 membutuhkan keterlibatan guru secara langsung. Menurut (Maprokhi, 2015) Perangkat pembelajaran memiliki peranan yang penting untuk mencapai tujuan pembelajaran karena dijadikan pedoman oleh guru sehingga proses pelaksanaan pembelajaran dapat terlaksana dengan baik.

Perangkat pembelajaran ini berbentuk Rencana Pelaksanaan Pembelajaran (RPP) beracuan pada Standar Isi yang dikembangkan dan disesuaikan oleh guru mata pelajaran (Revita \& Fitri, 2019). Rencana pembelajaran adalah hasil yang paling utama dari kegiatan pembelajaran yang mana guru memiliki hak untuk merumuskan pernyataan mereka (Latifa, 2017). Selain itu, (Rindarti, 2018) juga menjelaskan bahwa dalam menyusun RPP, setiap guru wajib menyusunnya secara lengkap dan terarah agar pembelajaran dapat dilaksanakan dengan baik. Menurut (Saryati, 2014) dibutuhkan beberapa persiapan dalam perencanaan pembelajaran yang mencakup paling sedikit tiga kegiatan yaitu identifikasi kebutuhan, identifikasi kompetensi dan penyusunan program pembelajaran yang bermuara pada RPP sebagai program jangka pendek.

Kompetensi menyusun RPP menurut (Aminullah \& Kusmianti, 2018) adalah kemampuan yang dimiliki oleh guru dalam menyusun dan mengembangkan RPP berdasarkan kurikulum yang memuat komponen-komponen RPP. Komponen-komponen Rencana Pelaksanaan Pembelajaran (RPP) berdasarkan (Kemendikbud, 2016) Nomor 22 terdiri dari: a) Identitas sekolah yaitu nama satuan pendidikan, b) Identitas mata pelajaran atau tema/subtema, c) Kelas/semester, d) Materi pokok, e) 
Alokasi waktu, f) Tujuan pembelajaran yang dirumuskan berdasarkan KD, dengan menggunakan kata kerja operasional yang dapat diamati dan diukur, yang mencakup sikap, pengetahuan, dan keterampilan, g) Kompetensi dasar dan indikator pencapaian kompetensi, h) Materi pembelajaran, memuat fakta, konsep, prinsip, dan prosedur yang relevan, dan ditulis dalam bentuk butir-butir sesuai dengan rumusan indikator ketercapaian kompetensi, i) Metode pembelajaran, j) Media pembelajaran, k) Sumber belajar, dapat berupa buku, media cetak dan elektronik, alam sekitar, atau sumber belajar lain yang relevan, l) Langkah-langkah pembelajaran dilakukan melalui tahapan pendahuluan, inti, dan penutup, m) Penilaian hasil pembelajaran.

Salah satu masalah penyebab kesulitan guru dalam menyusun RPP yaitu dikarenakan kurangnya pemahaman guru terhadap kurikulum 2013, masalah ini yang sering dijumpai guru sehingga menyebabkan guru tidak termotivasi dalam merancangnya (Palobo \& Tembang, 2019). Hasil penelitian yang dilakukan oleh (Ernawati \& Safitri, 2018) tentang analisis kesulitan guru dalam merancang rencana pelaksanaan pembelajaran menyatakan bahwa RPP yang telah disusun belum sesuai dengan tuntutan kurikulum 2013. Beberapa kesulitan yang ditemuinya adalah belum mendapatkan pelatihan kurikulum 2013, merumuskan indikator, pemilihan pendekatan/metode/strategi pembelajaran, mengembangkan aktivitas pembelajaran serta menyusun teknik dan instrumen penelitian. Hasil penelitian (Lamote, 2017) tentang kesulitan guru dalam melaksanakan pembelajaran kurikulum 2013, guru mengalami kesulitan dalam mengalokasikan waktu, menentukan metode pembelajaran yang sesuai dengan materi, guru masih kesulitan dalam menggunakan berbagai sumber belajar dan hanya menggunakan satu jenis buku paket matematika saja. Hasil penelitian yang dijelaskan oleh (Krisdiana et al., 2014) tentang kesulitan yang dihadapi guru didapat bahwa guru sekolah menengah pertama mengalami kesulitan dalam memahami tujuan kurikulum 2013 dan penggunaan pendekatan saintifik dalam pembelajaran, penggunaan bahasa dalam buku teks yang sulit dipahami oleh guru.

Dari uraian di atas dapat disimpulkan bahwa dalam merancang RPP, masih banyak kesulitan yang guru hadapi, diantaranya guru masih mengalami kesulitan dalam memahami tujuan, mengalokasikan waktu, menentukan pendekatan/metode/strategi pembelajaran, menggunakan berbagai sumber, masih kesulitan dalam memahami bahasa dalam buku teks. Atas dasar tersebut, maka penelitian difokuskan pada analisis kesulitan yang dihadapi guru matematika SMP dalam menyusun RPP yang berdasarkan kurikulum 2013, yang bertujuan untuk menganalisis dan mengetahui kesulitan yang dihadapi oleh guru dalam menyusun RPP kurikulum 2013. Penelitian ini dilaksanakan pada guru sekolah menengah pertama di kecamatan Kuala Kampar, Kabupaten Pelalawan.

\section{METODE}

Penelitian ini dilakukan di Kecamatan Kuala Kampar, Kabupaten Pelalawan. Menurut data referensi Kementrian Pendidikan dan Kebudayaan terdapat 7 (tujuh) SMP yang berstatus negeri di Kecamatan Kuala Kampar. SMP yang berstatus negeri dikategorikan berdasarkan akreditasi sekolah 
yaitu sekolah dengan akreditasi A dikategorikan kedalam sekolah yang amat baik dan sekolah yang dengan akreditasi B dan C, dikategorikan kedalam sekolah yang sedang dan kurang

Penelitian ini dilaksanakan di semester ganjil tahun ajaran 2020/2021. Populasi penelitian adalah seluruh guru mata pelajaran matematika tingkat SMP yang berada di Kecamatan Kuala Kampar, Kabupaten Pelalawan. Sampel penelitian menggunakan teknik purposive sampling. (Ernawati \& Safitri, 2018) menyatakan bahwa teknik purposive sampling adalah teknik pengambilan sampel berdasarkan tujuan tertentu. Pemilihan sampel ini berdasarkan kemudahan peneliti dalam melakukan penelitian karena terdapat dua sekolah yang terkendala dalam hal jaringan komunikasi sehingga peneliti memilih lima sekolah di Kecamatan Kuala Kampar. Sampel dari penelitian berjumlah 5 orang dengan setiap sekolah terdapat 1 orang guru matematika. Diantaranya 1 orang guru SMPN 1 Kuala Kampar (A1), 1 orang guru dari SMPN 2 Kuala Kampar (A2), 1 orang guru dari SMPN 3 Kuala Kampar (A3), 1 orang guru dari SMPN 5 Kuala Kampar (A4) dan 1 orang guru dari SMPN 6 Kuala Kampar (A5). Selain itu, guru yang dipilih menjadi sampel penelitian adalah guru yang bersedia untuk diwawancara mengenai penyusunan RPP.

Jenis penelitian yang digunakan adalah penelitian deskriptif kualitatif. (Husadaningsih \& Darajat, 2019) menyatakan bahwa penelitian kualitatif adalah penelitian yang bersifat deskriptif, penelitian yang sesuai dengan fakta dilapangan. Penelitian ini dilakukan untuk menganalisis kesulitan guru SMP matematika dalam menyusun RPP berdasarkan kurikulum 2013. Teknik pengumpulan data yang digunakan adalah wawancara dan dokumentasi. Wawancara dilakukan pada masing-masing guru matematika. Sedangkan dokumentasi dilakukan dengan mengumpulkan lima RPP yang telah dibuat oleh guru matematika Kecamatan Kuala Kampar, Kabupaten Pelalawan. Terdapat dua jenis data dalam penelitian ini, yaitu data primer dan data sekunder. Untuk memperoleh data primer, peneliti melakukan wawancara. Sedangkan untuk mendapatkan data sekunder didapat dari sumber RPP guru matematika. Untuk melihat kesulitan guru dalam merancang RPP, peneliti menganalisis beberapa komponen yang ada di RPP yaitu: (1) Kompentensi dasar dan indikator pencapaian kompentensi, dalam komponen ini peneliti melihat kesesuaian KKO yang ada dikompetensi dasar dan indikator pencapaian kompetensi; (2) Tujuan pembelajaran, untuk komponen tujuan pembelajaran ini peneliti melihat apakah tujuan pembelajaran yang dibuat oleh guru telah memuat rumus ABCD; (3) Materi pembelajaran, dalam komponen materi pembelajaran ini, peneliti melihat apakah dalam komponen ini telah memuat fakta, konsep, prinsip dan prosedur. Setelah menganalisis dan mengetahui kesalahan yang terdapat di komponen RPP tersebut, peneliti melakukan wawancara dengan kelima guru matematika yang bertujuan untuk memperkuat data yang telah peneliti peroleh.

\section{HASIL DAN DISKUSI}

Hasil penelitian yang telah dilakukan oleh peneliti yang mana pada proses ini RPP yang dibuat oleh guru matematika di analisis sesuai dengan Permendikbud No. 22 Tahun 2016 tentang standar proses 
Analisis Kesulitan Guru Matematika SMP dalam Menyusun Rencana Pelaksanaan Pembelajaran (RPP) Berdasarkan Kurikulum 2013, Rezkiatu Novia Alhikmah, Yenita Roza, Maimunah

dan kemudian dilakukan wawancara. Hasil analisis dari dokumen RPP dan wawancara tersebut adalah sebagai berikutt

\section{Hasil Analisis Komponen RPP}

\section{Komponen Kompetensi Dasar dan Indikator Pencapaian Kompetensi}

Komponen kompetensi dasar dan indikator pencapaiaan komptensi dapat dilihat pada gambar 1 .

\begin{tabular}{|c|c|c|}
\hline NO & Kompetensi Dasar (KD) & Indikator Pencapaian Kompetensi (IPK) \\
\hline 1. & $\begin{array}{l}\text { Menjelaskan rasio dua besaran } \\
\text { (satuannya sama dan berbeda). }\end{array}$ & $\begin{array}{l}\text { 3.7.1 Membedakan masalah yang berkaitan } \\
\text { dengan perbandingan (rasio) dan yang } \\
\text { bukan. } \\
\text { 3.7.2 Menielaskan tarif, kelajuan, kurs dari } \\
\text { 3.7.3 Matuan yang berbeda. } \\
\text { dengan perbandingan (rasio). }\end{array}$ \\
\hline 2. & $\begin{array}{l}\text { Menyelesaikan masalah yang } \\
\text { berkaitan dengan rasio dua } \\
\text { besaran (satuannya sama dan } \\
\text { berbeda). }\end{array}$ & $\begin{array}{l}\text { 4.7.1 Membuat suatu perbandingan senilai untuk } \\
\text { menentukan nilai x dalam } 5=2=10=\mathrm{x} \text {. } \\
\text { 4.7.2 Membedakan masalah perbandingan } \\
\text { senilai dan berbalik nilai dengan } \\
\text { menggunakan tabel, grafik dan persamaan. }\end{array}$ \\
\hline
\end{tabular}

Gambar 1. Komponen Kompetensi Dasar dan Indikator Pencapaian Kompetensi SMP A1

Gambar 1. menunjukkan bahwa komponen RPP tentang kompetensi dasar dan indikator pencapaian kompetensi yang dibuat oleh responden A1 terdapat kesalahan dalam menentukan kata kerja operasional (KKO). KKO yang terdapat di indikator 3.7.2 seharusnya tidak menggunakan KKO "menjelaskan" lagi, akan lebih baik KKO yang digunakan dalam indikator setara atau lebih rendah dari KKO dalam KD. Sedangkan KKO di indikator 3.7.3 dan 4.7.2 tidak sesuai dengan ranah yang seharusnya, dimana $\mathrm{KKO}$ yang digunakan dalam indikator 3.7.3 adalah KKO yang terdapat di ranah keterampilan dan KKO yang digunakan dalam indikator 4.7.2 terdapat di ranah pengetahuan.

\section{Komponen Tujuan Pembelajaran}

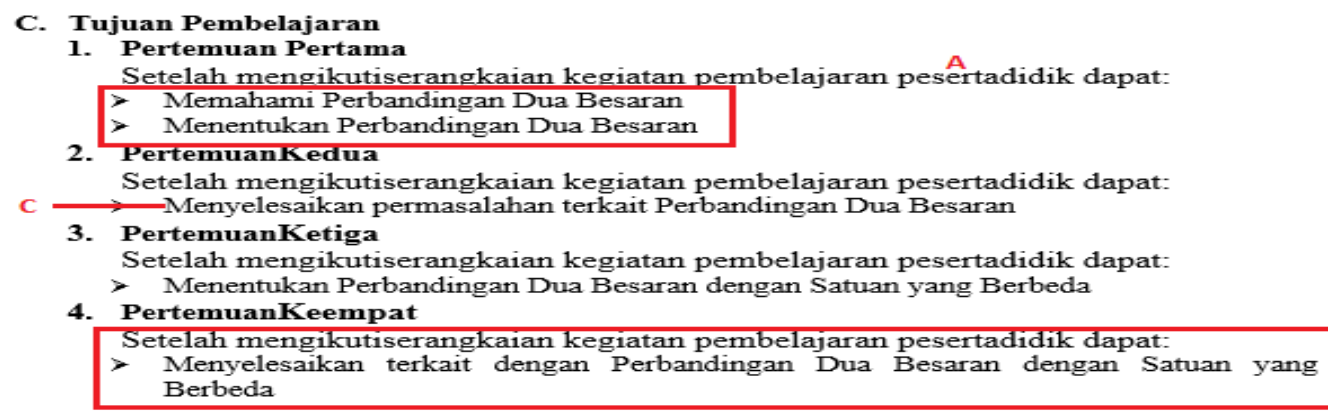

Gambar 2. Komponen Tujuan Pembelajaran SMP A1

Gambar 2 menunjukkan bahwa dalam membuat tujuan pembelajaran masih belum memenuhi rumus ABCD yaitu (audience, behavior, condition, degree). Dari gambar tersebut responden A1 hanya menggunakan audience dan condition. Dan KKO yang digunakan dalam tujuan pembelajaran tidak berkaitan dengan $\mathrm{KKO}$ yang ada di indikator ataupun $\mathrm{KD}$. 


\section{Komponen Materi Pembelajaran}

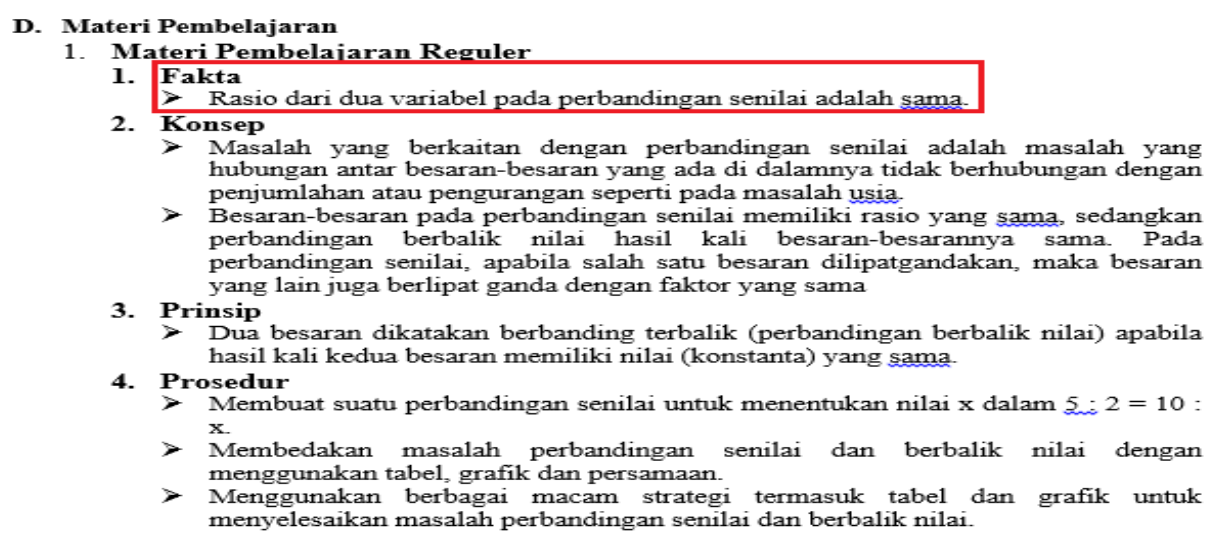

Gambar 3. Komponen Materi Pembelajaran SMP A1

Gambar 3 menunjukkan bahwa dalam komponen materi pembelajaran, responden A1 tidak memaparkan simbol yang seharusnya terletak di fakta berkaitan dengan materi rasio dari dua variabel pada perbandingan senilai.

\section{Hasil Wawancara di SMP AI}

Hasil wawancara dilakukan kepada responden A1. Tujuan dari wawancara ini untuk mengetahui kesulitan guru dalam menyusun RPP Kurikulum 2013. Berikut hasil wawancara, yaitu:

1. Responden pernah mengikuti pelatihan kurikulum 2013

2. Dalam penyusunan RPP, responden mendapatkan format baku RPP dari sekolah kemudian memodifikasi RPP tersebut sesuai dengan keadaan kelas dan forum MGMP lebih sering digunakan sebagai wadah untuk membuat soal ujian.

3. Responden bingung dalam menentukan KKO di indikator pencapaian kompetensi dan kurangnya pengetahuan tentang KKO yang ada di setiap ranah baik itu sikap, pengetahuan dan keterampilan.

4. Kurangnya pengetahuan responden tentang rumus $A B C D$ yang ada di tujuan pembelajaran.

5. Dalam penyusunan RPP tentang komponen materi pelajaran, responden terkadang masih bingung dalam menentukan fakta dan konsep. Responden masih berpikir bahwa fakta dan konsep bisa digabung menjadi satu.

\section{Hasil Analisis Komponen RPP}

\section{Komponen Kompetensi Dasar dan Indikator Pencapaian Kompetensi}

\begin{tabular}{|c|c|c|}
\hline \multicolumn{2}{|r|}{ Kompetensi Dasar (KD) } & Indikator Pencapaian Kompetensi (IPK) \\
\hline 3.1 & $\begin{array}{l}\text { Menjelaskan dan melakukan } \\
\text { operasi bilangan berpangkat bulat } \\
\text { dan bentuk akar, serta sifat- } \\
\text { sifatnya }\end{array}$ & $\begin{array}{ll}3.1 .1 & \begin{array}{l}\text { Mengidentifikasi operasi bilangan } \\
\text { berpangkat bulat dan bentuk akar, serta } \\
\text { sifat-sifatnya }\end{array} \\
\text { 3.1.2 } & \begin{array}{l}\text { Menganalisis operasi bilangan } \\
\text { berpangkat bulat dan bentuk akar, serta } \\
\text { sifat-sifatnya }\end{array}\end{array}$ \\
\hline 4.1 & $\begin{array}{l}\text { Menyelesaikan masalah yang } \\
\text { berkaitan dengan sifat-sifat operasi } \\
\text { bilangan berpangkat bulat dan } \\
\text { bentuk akar }\end{array}$ & $\begin{array}{l}\text { Menyederhanakan sifat-sifat operasi } \\
\text { bilangan berpangkat bulat dan bentuk } \\
\text { akar } \\
\text { Menghitung bilangan berpangkat bulat } \\
\text { dan bentuk akar }\end{array}$ \\
\hline
\end{tabular}

Gambar 4. Komponen Kompetensi Dasar dan Indikator Pencpaian Kompetensi SMP A2 
Gambar 4 menunjukkan bahwa komponen RPP tentang kompetensi dasar dan indikator pencapaian kompetensi yang dibuat oleh responden $\mathbf{A 2}$ masih kurang tepat dalam menentukan kata kerja operasional (KKO). KKO di indikator 4.1.1 dan 4.1.2 tidak sesuai dengan ranah yang seharusnya, dimana KKO yang digunakan dalam indikator 4.1.1 dan 4.1.2 adalah KKO yang terdapat di ranah pengetahuan.

\section{Komponen Tujuan Pembelajaran}

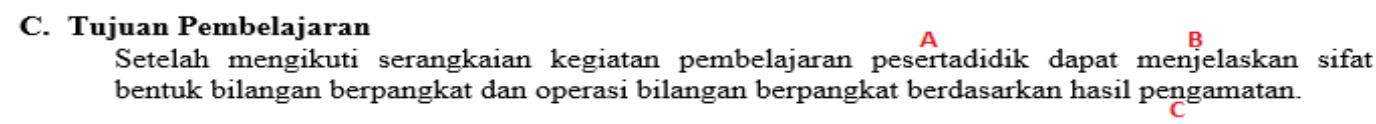

Gambar 5. Komponen Tujuan Pembelajaran SMP A2

Gambar 5 menunjukkan bahwa dalam membuat tujuan pembelajaran hampir memenuhi rumus ABCD yaitu (audience, behavior, condition, degree). Dari gambar tersebut responden A2 hanya tidak memasukkan degree dalam tujuan pembelajaran.

\section{Komponen Materi Pembelajaran}

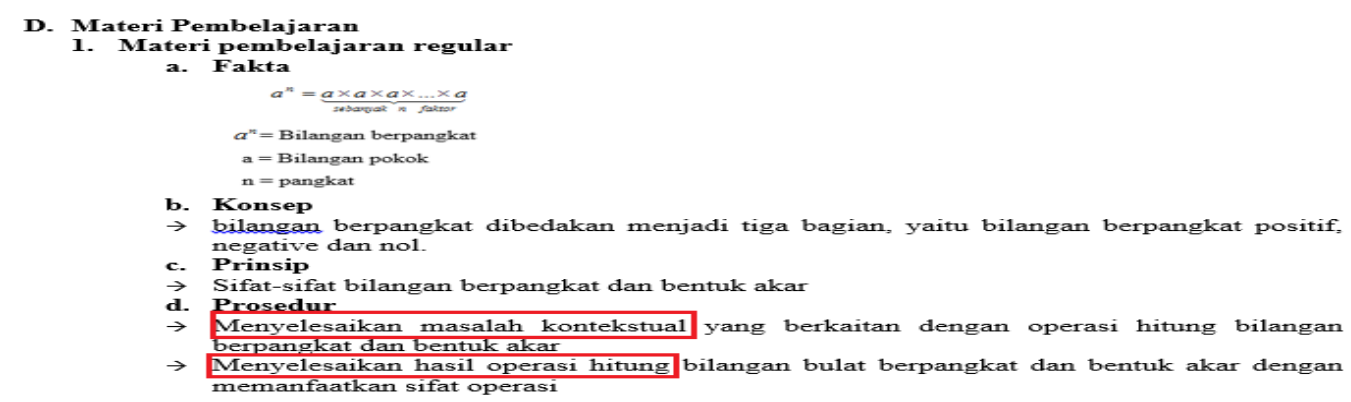

Gambar 6. Komponen Materi Pembelajaran SMP A2

Gambar 6 menunjukkan bahwa dalam komponen materi pembelajaran, responden A2 kurang tepat dalam membuat prosedur yang ada di materi pembelajaran. Prosedur yang dibuat tidak memaparkan langkah-langkah dari operasi hitung, yang mana prosedur merupakan langkah-langkah yang sistematis atas terjadinya sesuatu.

\section{Hasil Wawancara di SMP A2}

Hasil wawancara dilakukan kepada responden A2. Tujuan dari wawancara ini untuk mengetahui kesulitan guru dalam menyusun RPP Kurikulum 2013. Berikut hasil wawancara, yaitu:

1. Responden pernah mengikuti pelatihan kurikulum 2013

2. Dalam penyusunan RPP, responden memodifikasi RPP yang di dapat dari sekolah dan disesuaikan dengan keadaan kelas.

3. Responden menganggap bahwa KKO yang ada diranah pengetahuan sama dengan ranah keterampilan.

4. Responden telah memahami rumus $\mathrm{ABCD}$ yang ditetapkan dalam membuat tujuan pembelajaran.

5. Responden telah memahami tentang fakta, konsep, prinsip dan prosed yang ada dimateri pelajaran. 


\section{Hasil Analisi Komponen RPP}

\section{Komponen Kompetensi Dasar dan Indikator Pencapaian Kompetensi}

\begin{tabular}{|c|c|}
\hline Kompetensi Dasar & Indikator \\
\hline $\begin{array}{l}\text { 3.4 Menjelaskan himpunan, himpunan bagian, } \\
\text { himpunan semesta, himpunan kosong, } \\
\text { komplemen himpunan, dan melakukan } \\
\text { operasi biner pada himpunan menggunakan } \\
\text { masalah kontekstual }\end{array}$ & $\begin{array}{l}\text { 3.4.1. Menyatakan masalah sehari-hari dalam } \\
\text { bentuk himpupan dan mendata anggotanya; } \\
\text { 3.4.2. Menyebutkan anggota dan bukan anggota } \\
\text { 3.4.3. } \begin{array}{l}\text { Menyajikan himpunan dengan menyebutkan } \\
\text { anggotanya }\end{array}\end{array}$ \\
\hline $\begin{array}{l}\text { 4.4 Menyelesaikan masalah kontekstual yang } \\
\text { berkaitan dengan himpunan, himpunan } \\
\text { bagian, himpunan semesta, himpunan } \\
\text { kosong, komplemen himpunan dan operasi } \\
\text { biner pada himpunan }\end{array}$ & $\begin{array}{lll}\text { 4.4.1. Menyelesaikan masalah kontekstual } & \text { yang } \\
\text { berkaitan dengan diagram Venn } & \\
\text { 4.4.2. } & \text { Menyelesaikan masalah kontekstual yang } \\
& \text { berkaitan dengan irisan dua himpunan } & \end{array}$ \\
\hline
\end{tabular}

Gambar 7. Komponen Kompetensi Dasar dan Indikator Pencapaian Kompetensi SMP A3

Gambar 7 menunjukkan bahwa komponen RPP tentang kompetensi dasar dan indikator pencapaian kompetensi yang dibuat oleh responden A3 kurang tepat dalam menentukan kata kerja operasional (KKO). KKO yang terdapat di indikator 3.4.2 akan lebih baik tidak menggunakan kata "menyebutkan" karena kata tersebut tidak dapat diukur. Responden bisa mengganti dengan kata kerja "memberi contoh". Selain itu, KKO untuk indikator 4.4.1 dan 4.4.2 menggunakan KKO yang ada di KD. Akan lebih baik, responden $\mathbf{A 3}$ menggunakan KKO lain untuk diindikator namun masih setara tingkatannya.

\section{Komponen Tujuan Pembelajaran}

C. Tujuan Pembelajaran

Setelah menximak penjelasan guru, peserta didik dapat:

- Menyatakan masalah sehari-hari dalam bentuk himpunan dan mendata anggotanya:

- Menyebutkan anggota dan bukan anggota himpunan:

- Menyajikan himpunan dengan menyebutkan anggotanya

\section{Gambar 8. Komponen Tujuan Pembelajaran SMP A3}

Gambar 8 menunjukkan bahwa dalam membuat tujuan pembelajaran, responden $\mathbf{A 3}$ hanya tidak menggunakan degree.

\section{Komponen Materi Pembelajaran}

D. Materi Pembelajaran

- Konsep Himpunan

- Penyajian Himpunan, Himpunan Kosong dan Himpunan Semesta, serta Diagram Venn

- Sifat-sifat Himpunan $\Rightarrow$ PRINSIP

Gambar 9. Komponen Materi Pembelajaran SMP A3

Gambar 9 menunjukkan bahwa dalam komponen materi pembelajaran, responden A3 tidak menyajikan fakta dan prosedur. Untuk konsep dan prinsip, responden A3 hanya menyebutkan saja tanpa menjelaskan secara rinci.

\section{Hasil Wawancara di SMP A3}

Hasil wawancara dilakukan kepada responden A3. Tujuan dari wawancara ini untuk mengetahui kesulitan guru dalam menyusun RPP Kurikulum 2013. Berikut hasil wawancara, yaitu:

1. Responden pernah mengikuti pelatihan kurikulum 2013 
2. Dalam penyusunan RPP, responden membuat sendiri RPP sesuai dengan kondisi kelas yang diajarkan.

3. Responden mengalami kesulitan dalam merumuskan indikator pencapaian kompetensi, dimana responden kurangnya pemahaman responden dalam menentukan KKO untuk indikator pencapaian kompetensi

4. Responden telah memahami rumus ABCD namun masih bingung dengan tata letaknya ditujuan pembelajaran, apakah harus berurutan atau boleh diletakkan dimana saja asalkan memenuhi rumus ABCD.

5. Kurangnya pengetahuan responden terhadap fakta, konsep, prinsip dan prosedur. Sehingga responden menjelaskan bahwa dalam penyusunan RPP responden hanya menyebutkan saja tanpa menjelaskan secara rinci.

\section{Hasil Analisis Komponen RPP}

\section{Komponen Kompetensi Dasar dan Indikator Pencapaian Kompetensi}

\begin{tabular}{|c|c|}
\hline Kompetensi Dasar & Indikator Pencapaian Kompetensi \\
\hline $\begin{array}{l}\text { 3.2 Menjelaskan dan melakukan } \\
\text { operasi hitung bilangan bulat } \\
\text { dan pecahan dengan } \\
\text { memanfaatkan berbagai sifat } \\
\text { operasi }\end{array}$ & $\begin{array}{l}\text { 3.2.1. Menentukan hasil operasi hitung } \\
\text { penjumlahan dan pengurangan pada bilangan bulat } \\
\text { 3.2.2. Menyelesaikan hasil operasi hitung } \\
\text { penjumlahan dan pengurangan bilangan bulat }\end{array}$ \\
\hline $\begin{array}{l}\text { 4.2 Menyelesaikan masalah yang } \\
\text { berkaitan dengan operasi } \\
\text { hitung bilangan bulat dan } \\
\text { pecahan }\end{array}$ & $\begin{array}{l}\text { 4.2.1 Menyelesaikan masalah dunia nyata yang } \\
\text { berkaitan dengan operasi hitung bilangan } \\
\text { bulat }\end{array}$ \\
\hline
\end{tabular}

Gambar 10. Komponen Kompetensi Dasar dan Indikator Pencapaian Kompetensi SMP A4

Gambar 10 menunjukkan bahwa komponen RPP tentang kompetensi dasar dan indikator pencapaian kompetensi yang dibuat oleh responden A4 terdapat kesalahan dalam menentukan kata kerja operasional (KKO). KKO di indikator 3.2.2 tidak diranah pengetahuan melainkan KKO yang digunakan dalam indikator 3.2.2 adalah KKO yang terdapat di ranah keterampilan yang harusnya KKO untuk indikator tersebut menggunakan KKO di ranah pengetahuan. Selain itu, KKO untuk indikator 4.2.1 menggunakan KKO yang ada di KD. Akan lebih baik, responden A4 menggunakan KKO lain untuk diindikator namun masih setara tingkatannya.

\section{Komponen Tujuan Pembelajaran}

C. Tujuan Pembelajaran A Melalui diskusi kelompok Siswa dapat:

B

1. Menentukan hasil operasi hitung bilangan bulat pada penjumlahan dan pengurangan

2. Menyelesaikan masalah yang berkaitan dengan bilangan bulat Gambar 11. Komponen Tujuan Pembelajaran SMP A4

Gambar 11 menunjukkan bahwa dalam membuat tujuan pembelajaran sudah memenuhi sebagian besar rumus $\mathrm{ABCD}$ yaitu (audience, behavior, condition, degree). Responden $\mathbf{A 4}$ tidak menggunakan degree. 


\section{Komponen Materi Pembelajaran}

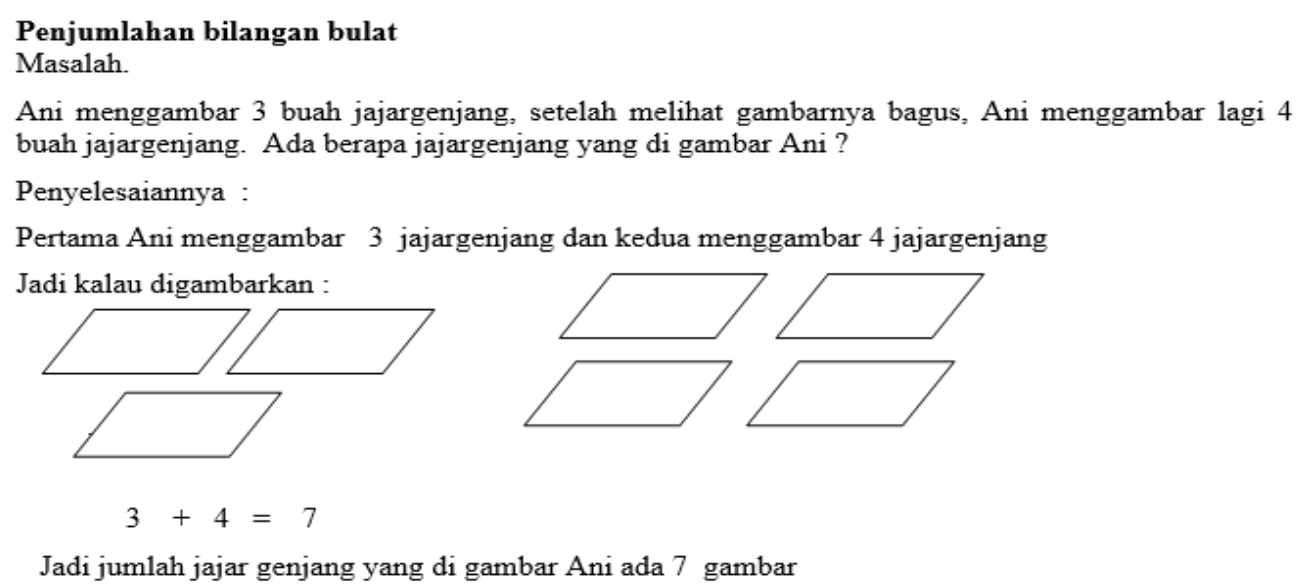

Gambar 12. Komponen Materi Pembelajaran SMP A4

Gambar 12 menunjukkan bahwa dalam komponen materi pembelajaran, responden A4 tidak menyajikan konsep, fakta, prinsip. Responden hanya menyajikan soal yang kemudian ditentukan langkah-langkah penyelesaiannya.

\section{Hasil Wawancara di SMP A4}

Hasil wawancara dilakukan kepada responden A4. Tujuan dari wawancara ini untuk mengetahui kesulitan guru dalam menyusun RPP Kurikulum 2013. Berikut hasil wawancara, yaitu:

1. Responden pernah mengikuti pelatihan kurikulum 2013

2. Dalam penyusunan RPP, responden membuat sendiri RPP nya yang disesuaikan dengan keadaan kelas yang diajar.

3. Responden masih kurang paham dalam menentukan KKO di indikator pencapaian kompetensi dan tidak mengetahui bahwa KKO di ranah pengetahuan berbeda dengan ranah keterampilan. Responden juga bingung dalam menentukan KKO mana yang cocok saat membuat indikator pencapaian kompetensi.

4. Responden sudah memahami rumus $A B C D$ yang ada ditujuan pembelajaran, namun masih bingung dalam menentukan degree dan juga bingung dengan tata letak $\mathrm{ABCD}$ tersebut.

5. Dalam penyusunan RPP tentang komponen materi pelajaran, kurangnya pengetahuan responden dalam menentukan fakta, konsep, prinsip dan prosedur. Akibat kurangnya pemahaman tentang fakta, konsep, prinsip dan prosedur sehingga responden belum bisa membedakan antara keempat unsur tersebut.

\section{Hasil Analisis Komponen RPP di SMP A5}

\section{Komponen Kompetensi Dasar dan Indikator Pencapaian Kompetensi}

Pada gambar 13 berikut menunjukkan bahwa komponen RPP tentang kompetensi dasar dan indikator pencapaian kompetensi yang dibuat oleh responden A5 kurang tepat dalam menentukan kata kerja operasional (KKO). KKO yang terdapat di indikator 3.4.2 akan lebih baik tidak menggunakan kata “menyebutkan" karena kata tersebut tidak dapat diukur. Responden bisa mengganti dengan kata kerja 
“memberi contoh". Sedangkan KKO di indikator 4.4.2 tidak sesuai dengan ranah yang seharusnya, dimana KKO yang digunakan dalam indikator 4.4.2 adalah KKO yang terdapat di ranah pengetahuan. Selain itu, KKO untuk indikator 4.4.1 menggunakan KKO yang ada di KD. Akan lebih baik, responden A5 menggunakan KKO lain untuk diindikator namun masih setara tingkatannya.

\begin{tabular}{|c|c|c|}
\hline No & Kompetensi Dasar (KD) & Indikator Pencapaian Kompetensi (IPK) \\
\hline 1. & $\begin{array}{l}\text { 3.4 Menjelaskan dan menyatakan } \\
\text { himpunan, } \\
\text { bagian,himpunan semesta, } \\
\text { himpunan kosong,komplemen } \\
\text { himpunan menggunakan } \\
\text { masalah kontekstual }\end{array}$ & $\begin{array}{l}\text { 3.4.1 Menyatakan masalah } \begin{array}{l}\text { sehari-hari } \\
\text { dalam bentuk himpunan dan mendata }\end{array} \\
\text { anggotanva: } \\
\text { 3.4.2 } \begin{array}{l}\text { Menyebutkan anggota dan bukan } \\
\text { anggotahimpunan; }\end{array} \\
\text { 3.4.3 Menyajikan himpunan dengan } \\
\text { menyebutkan anggotanya }\end{array}$ \\
\hline 2. & $\begin{array}{lr}\text { 4.4 Menyelesaikan } & \text { masalah } \\
\text { konstekstual yang berkaitan } \\
\text { dengan himpunan, himpunan } \\
\text { bagian, himpunan semesta, } \\
\text { himpunan } & \text { kosong, } \\
\text { komplemenhimpunan, dan } \\
\text { operasi pada himpunan untuk } \\
\text { menyajikan } & \text { masalah } \\
\text { kontekstual } & \end{array}$ & $\begin{array}{l}\text { Menyelesaikan masalah } \\
\text { yang berkaitan dengan selisih dari } \\
\text { duahimpunan } \\
\text { Menyatakan sifat-sifat dari operasi } \\
\text { himpunan }\end{array}$ \\
\hline
\end{tabular}

Gambar 13. Komponen Kompetensi Dasar dan Indikator Pencapaian Kompetensi SMP A5

\section{Komponen Tujuan Pembelajaran}

\section{Tujuan Pembelajaran}

Melalui kegiatan pembelajaran menggunakan model Discovery Learning yang dipadukan dengan metode mind mapping, teknik ATM, dan pendekatan saintifik yang menuntun peserta didik untuk mengamati (membaca) permasalahan, menuliskan penyelesaian dan mempresentasikan hasilnya di depan kelas. Selama dan setelah mengikuti proses pembelajaran ini peserta didik diharapkan dapat: $>$ Menganalisis dan memahami Konsep Himpunan

$>$ Menghitung Penyajian Himpunan dengan rasa ingin tahu, tanggung jawab, displin selama proses pembelajaran, bersikap jujur, santun, percaya diri dan pantang menyerah, serta memiliki sikap responsif (berpikir kritis) dan pro-aktif (kreatif), serta mampu berkomukasi dan bekerjasama dengan baik

Gambar 14. Komponen Tujuan Pembelajaran SMP A5

Gambar 14 menunjukkan bahwa dalam membuat tujuan pembelajaran responden A5 sudah memenuhi rumus $\mathrm{ABCD}$ yaitu (audience, behavior, condition, degree). Meskipun responden telah memenuhi semua rumus ABCD yang ada di tujuan pembelajaran. Namun KKO yang digunakan dalam tujuan pembelajaran ini tidak sesuai dengan KKO yang ada di KD maupun indikator.

\section{Komponen Materi Pembelajaran}

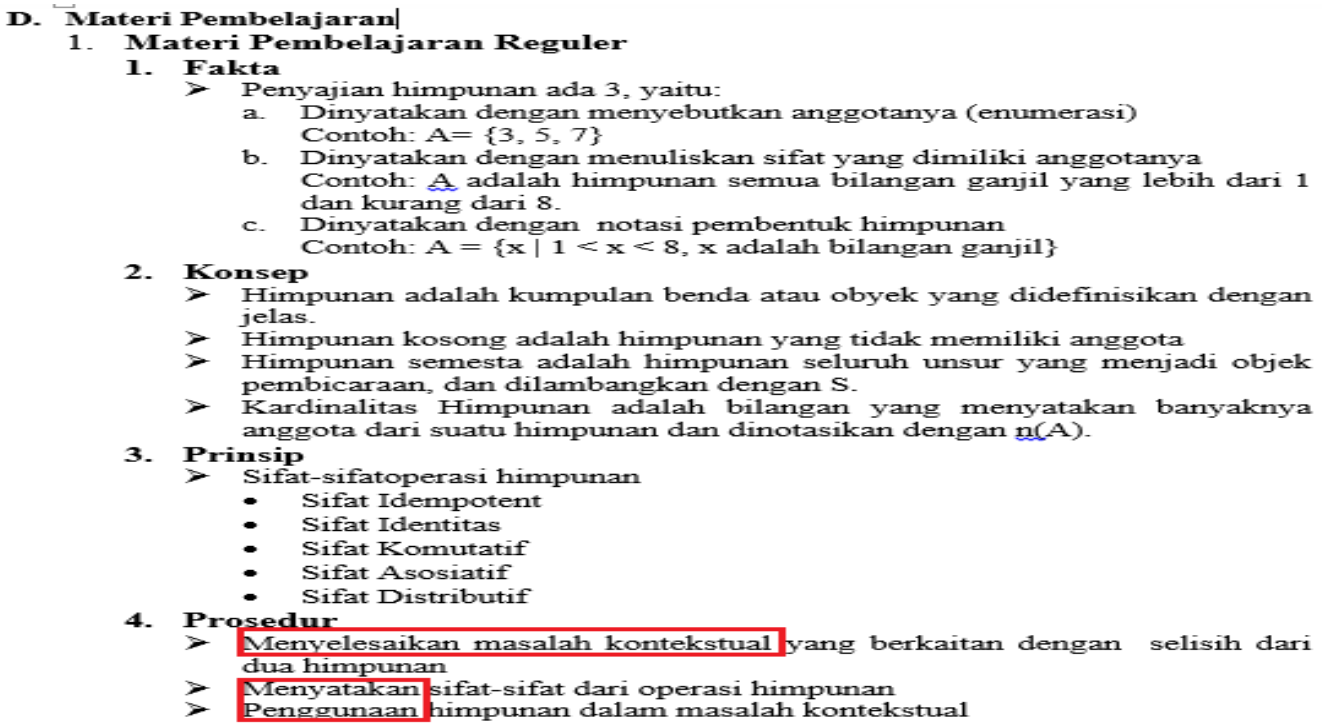

Gambar 15. Komponen Materi Pembelajaran SMP A5 
Gambar 15 menunjukkan bahwa dalam komponen materi pembelajaran, responden A5 hanya kurang tepat dalam menentukan prosedur. Karena prosedur merupakan langkah-langkah dari suatu kegiatan maka akan lebih baik responden A5 menyajikan langkah-langkah dari materi tersebut secara tepat dan ringkas.

\section{Hasil Wawancara}

Hasil wawancara dilakukan kepada responden A5. Tujuan dari wawancara ini untuk mengetahui kesulitan guru dalam menyusun RPP Kurikulum 2013. Berikut hasil wawancara, yaitu:

1. Responden pernah mengikuti pelatihan kurikulum 2013

2. Dalam penyusunan RPP, responden membuat RPP sendiri.

3. Responden masih bingung dalam menentukan $\mathrm{KKO}$ di indikator pencapaian kompetensi dan kurangnya pengetahuan tentang KKO yang ada di setiap ranah baik itu sikap, pengetahuan dan keterampilan.

4. Responden memahami tentang rumus $\mathrm{ABCD}$ yang ada di tujuan pembelajaran, namun terdapat kesalahpahaman bahwa dalam menentukan behavior di tujuan pembelajaran harus membuat dengan KKO yang baru. Yang mana seharusnya menurut permendikbud no 22 tahun 2016 tujuan pembelajaran dirumuskan berdasarkan KD. Sehingga KKO yang digunakan juga berdasarkan KD dan IPK yang telah ditentukan sebelumnya.

Responden kurang memahami bahwa prosedur yang ada di materi pelajaran digunakan untuk menjelaskan langkah-langkah dalam menyelesaikan suatu masalah yang ada dimateri.

Hasil analisis dari kelima RPP yang diperkuat dengan hasil wawancara yang menunjukkan kesulitan guru matematika dalam menyusun RPP. Maka terdapat beberapa aspek yang menunjukkan kesulitan guru dalam menyusun proses perencanaan pelaksanaan pembelajaran, diantaranya:

1. Guru kurang paham dan belum bisa menyesuaikan kata kerja operasional dalam membuat indikator pencapaian kompetensi. Guru belum mampu menggunakan kata kerja operasional yang sesuai dengan kompetensi yang diukur dan juga belum sesuai dengan tahapan taksonomi Bloom. Dari kelima dokumen RPP yang telah dianalisis, kelima guru yang membuat indikator, dimana kata kerja operasional dalam taksonomi Bloom yang harusnya digunakan pada ranah pengetahuan tetapi guru gunakan pada ranah keterampilan, selain itu juga didapat bahwa kata kerja operasional yang digunakan dalam membuat indikator sama dengan kata kerja operasional yang ada dikompetensi dasar, yang mana harusnya kata kerja yang digunakan dalam pembuatan indikator harus lebih rendah atau setara dengan kata kerja yang ada kompetensi dasar. Hal ini sejalan dengan pendapat (Sa'dun Akbar, 2017) yang menjelaskan bahwa tingkat kata kerja dalam indikator lebih rendah atau setara dengan kata kerja dalam KD. Indikator pembelajaran dibuat bertujuan untuk memberikan batasan kepada siswa dalam memahami pelajaran yang wajib ia kuasai dan juga untuk menyukseskan sebuah proses pelaksanaan pembelajaran sehingga tujuan yang diharapkan tercapai dengan waktu yang diinginkan. 
2. Masih kurangnya pemahaman guru tentang tujuan pembelajaran yang memperhatikan syarat Audience, Behavior, Condition dan Degree, terdapat juga kesalahpahaman guru yang mana dalam menentukan behavior harus membuat lagi KKO nya, selain itu guru bingung dengan tata letak dari ABCD ini. Bisakah diletakkan tidak berurutan atau harus sesuai urutan ABCD. Dari RPP yang disusun oleh kelima guru yang ada di kecamatan Kuala Kampar, tujuan pembelajaran pada RPP ada beberapa guru hanya mengandung unsur $\mathrm{ABC}$ saja bahkan ada yang hanya mengandung unsur $\mathrm{AB}$. Guru juga menjelaskan bahwa RPP yang dibuat oleh guru itu sendiri. Hal ini terjadi karena guru matematika disekolah tersebut tunggal untuk semua kelas, sehingga tidak ada teman berdiskusi tentang penyusunan RPP. Selain itu, MGMP yang merupakan forum untuk berdiskusi hanya digunakan untuk pembuatan soal ujian saja.

3. Guru tidak membuat materi ajar yang memuat fakta, konsep, prinsip dan prosedur dikarenakan guru masih kurang paham dalam menentukan unsur yang ada di materi pelajaran. Guru juga bingung dalam menentukan fakta dan konsep sehingga masih ada guru yang menggabungkan kedua hal tersebut. Akibat kurangnya pemahaman guru dalam komponen ini, sehingga masih ada guru ada yang hanya menyebutkan materi tanpa menjelaskannya secara ringkas dan rinci. Guru menjelaskan bahwa karena minimnya diskusi yang dilakukan, sehingga membuat guru kebingungan dalam menentukan fakta, konsep, prinsip maupun prosedur didalam materi ajar yang ada di RPP. Guru juga menjelaskan bahwa ada beberapa guru yang mendapatkan format baku RPP dari sekolah dan ada yang tidak, sehingga bagi sebagian guru yang tidak mendapat format baku, dalam menyusun materi ajar hanya memodifikasi dari RPP yang ada atau membuatnya sendiri.

Berdasarkan hasil analisis dari kelima RPP yang dikembangkan oleh guru matematika SMP Negeri di Kecamatan Kuala Kampar dapat disimpulkan bahwa guru di Kecamatan Kuala Kampar masih kesulitan dalam menyusun komponen RPP, sebagaimana hasil penelitian yang dilakukan oleh Markus Palobo dan Yonarlianto Tembang pada tahun 2019 yang berjudul "Analisis Kesulitan Guru dalam Implementasi Kurikulum 2013 di Kota Merauke”. Penelitian ini bertujuan untuk mendeskripsikan kesulitan yang dialami oleh guru sekolah menengah pertama dalam mengembangkan perangkat pembelajaran berdasarkan kurikulum 2013. Hasil pada penelitian ini menunjukkan bahwa guru di kota Merauke mengalami kesulitan dalam mengembangkan perangkat pembelajaran, kesulitan tersebut diantaranya (1) Pengembangan indikator pencapaian kompetensi; (2) Penyusunan skema pencapaian kompetensi dasar; (3) Pengembangan kegiatan apersepsi; (4) Pengembangan aktivitas kegiatan inti; (5) Perancangan kegiatan menarik kesimpulan; (6) Penyusunan penilaian.

\section{KESIMPULAN}

Kesulitan yang dialami oleh guru SMP di kecamatan Kuala Kampar dalam menyusun RPP kurikulum 2013 yaitu (1) Guru belum bisa menyesuaikan kata kerja operasional dalam membuat indikator pencapaian kompetensi; (2) Masih kurangnya pemahaman guru tentang tujuan pembelajaran yang memperhatikan syarat Audience, Behavior, Condition dan Degree; (3) Terdapat kesalahpahaman 
guru yang mana dalam menentukan behavior harus membuat lagi KKO nya; (4) Guru bingung dengan tata letak dari ABCD; (5) Guru juga bingung dalam menentukan fakta dan konsep sehingga masih ada guru yang menggabungkan kedua hal tersebut. Berdasarkan hasil dari analisis tersebut maka dapat disimpulkan bahwa guru masih kurang dalam mendapatkan pelatihan dan seminar sehingga informasi tentang penyusunan komponen RPP masih kurang didapat yang mengakibatkan guru masih bingung dalam penyusunan RPP. Berdasarkan kesimpulan yang telah dipaparkan, adapun solusi untuk mengatasi kesulitan guru diharapkan (1) Sekolah hendaknya memberikan fasilitas kepada guru untuk mengikuti pelatihan atau webinar tentang penyusunan komponen RPP; (2) Guru lebih banyak mencari dan membaca berbagai macam literatur tentang penyusunan RPP sehingga guru lebih mendapatkan banyak informasi dan pengetahuan dari literatur yang dibacanya tentang komponen yang ada di RPP dan juga (3) Mengaktifkan kembali peran MGMP yang ada di kecamatan Kuala Kampar agar sesama guru dapat saling bertukar informasi dalam merancang RPP.

\section{UCAPAN TERIMA KASIH}

Peneliti mengucapkan syukur yang tak terhingga kepada Allah SWT karena telah memberi kelancaran dan kemudahan dalam menyelesaikan artikel ini. Terimakasih kepada kedua orang tua, Bapak Sujono dan Ibu Mahyati karena telah memberikan dukungannya kepada peneliti. Peneliti juga berterimakasih kepada kepada dosen pebimbing, Ibu Yenita Roza, Ph. D dan Ibu Dr. Maimunah, M. Si. yang telah memberikan bimbingan dan arahan dalam menyelesaikan artikel ini.

\section{REFERENSI}

Aminullah, \& Kusmianti. (2018). Kompetensi Guru Matematika Pemula dalam Membuat Perangkat Pembelajaran SMP/MTs di Lombok Timur. Ganec Swara: Jurnal Unmasmataram, 12 (September), 116-124. http://journal.unmasmataram.ac.id/index.php/GARA

Ernawati, E., \& Safitri, R. (2018). Analisis Kesulitan Guru Dalam Merancang Rencana Pelaksanaan Pembelajaran Mata Pelajaran Fisika Berdasarkan Kurikulum 2013 Di Kota Banda Aceh. Jurnal Pendidikan Sains Indonesia, 5(2), 50-58. https://doi.org/10.24815/jpsi.v5i2.9817

Husadaningsih, T., \& Darajat, P. P. (2019). Analaisis Kesulitan Guru Matematika SMP dan MTS di Kabupaten Malang Menggunakan Pendekatan Saintifik. Jurnal Aksioma, 8(3), 474-484.

Kemendikbud. (2016). Permendikbud No 22 Tahun 2016 Tentang Standar Proses Pendidikan Dasar dan Menengah. August, 1-15.

Krisdiana, I., Apriandi, D., \& Setiansyah, R. K. (2014). Analisis Kesulitan Yang Dihadapi Oleh Guru Dan Peserta Didik Sekolah Menengah Pertama Dalam Implementasi Kurikulum 2013 Pada Mata Pelajaran Matematika (Studi Kasus Eks-Karesidenan Madiun). JIPM (Jurnal Ilmiah Pendidikan Matematika), 3(1). https://doi.org/10.25273/jipm.v3i1.492 
Lamote, H. (2017). Kesulitan-Kesulitan Guru Matematika dalam Melaksanakan Pembelajaran Kurikulum 2013 dI Madrasah Aliyah DDI LABIBIA. Jurnal Al-Ta’dib, 10(1), 55-72.

Latifa, I. S. (2017). The Analysis of Teachers' Lesson Plan Through Behavioural Objectives Theory. Advances in Social Science, Education and Humanities Research (ASSEHR), 82(Conaplin 9), 611. https://doi.org/10.2991/conaplin-16.2017.2

Maprokhi. (2015). Pengembangan Perangkat Pembelajaran Matematika untuk SMP Kelas VIII Semester Genap dengan Pendekatan Saintifik. PYTHAGORAS: Jurnal Pendidikan Matematika, 10(3), 168-178.

Palobo, M., \& Tembang, Y. (2019). Analisis Kesulitan Guru dalam Implementasi Kurikulum 2013 di $\begin{array}{llll}\text { Kota } & \text { Merauke. } & \text { 30batik, } & \text { 23(2), }\end{array}$ https://jurnal.wicida.ac.id/index.php/sebatik/article/view/775

Ratumanan, T. G., \& Tetelepta, Y. (2019). Analisis Pembelajaran Matematika Berdasarkan Kurikulum 2013 Pada Sma Negeri 1 Masohi. JUMADIKA : Jurnal Magister Pendidikan Matematika, 1(1), 25-34. https://doi.org/10.30598/jumadikavol1iss1year2019page25-34

Retnawati, H. (2016). Hambatan Guru Matematika Sekolah Menengah Pertama Dalam Menerapkan Kurikulum Baru. Jurnal Cakrawala Pendidikan, 3(3), 390-403. https://doi.org/10.21831/cp.v3i3.7694

Revita, R., \& Fitri, I. (2019). Evaluasi Pelaksanaan Kurikulum 2013 pada Tahap Perencanaan Dalam Pembelajaran Matematika Sma. Jurnal Cendekia: Jurnal Pendidikan Matematika, 3(1), 197-208.

Rindarti, E. (2018). Peningkatan Kompetensi Guru Dalam Mengembangkan Rpp Kurikulum 2013 Revisi 2017 Melalui Pendampingan Berkelanjutan Di MA Binaan Kota Jakarta Pusat Tahun Pelajaran 2017/2018. Jurnal Penelitian Kebijakan Pendidikan, 11(2), 1-19.

Sa’dun Akbar. (2017). Instrumen Perangkat Pembelajaran. Remaja Rosdakarya.

Sariono. (2014). Kurikulum 2013: Kurikulum Generasi Emas. E-Jurnal Dinas Pendidikan Kota Surabaya, 3 .

Saryati. (2014). Upaya Peningkatan Kompetensi Paedagogik Guru Sekolah Dasar. Bahana Manajemen Pendidikan Jurnal Administrasi Pendidikan, 2(1), 669-681.

Winaya, I. K., Suarjana, I. M., \& Mahadewi, L. P. P. (2015). Analisi Rencana Pelaksanaan Pembelajaran Menurut Kurikulum 2013 Kelas IV SD No. IV Banyuasri. E-Journal PGSD Universitas Pendidikan Ganesha, 3(1). 